Meta

Journal des traducteurs

Translators' Journal

\title{
Dubbing as an Expression of Nationalism
}

\section{Martine Danan}

Volume 36, numéro 4, décembre 1991

URI : https://id.erudit.org/iderudit/002446ar

DOI : https://doi.org/10.7202/002446ar

Aller au sommaire du numéro

Éditeur(s)

Les Presses de l'Université de Montréal

ISSN

0026-0452 (imprimé)

1492-1421 (numérique)

Découvrir la revue

Citer cet article

Danan, M. (1991). Dubbing as an Expression of Nationalism. Meta, 36(4),

606-614. https://doi.org/10.7202/002446ar

\section{Résumé de l'article}

On cherche à savoir pourquoi le public de certains pays préfère les films doublés alors qu'ailleurs les sous-titres sont plus populaires. Pour saisir l'importance accordée à chacune de ces formes de traduction dans un pays donné, il faut les étudier en tant que phénomènes linguistiques et en tant qu'éléments de l'expression cinématographique. Ce qui conduit à l'étude des différentes caractéristiques de la production cinématographique de divers pays. On démontre que le choix de la forme de traduction s'appuie sur divers facteurs d'identité culturelle et linguistique d'un pays ; il est possible d'identifier des constantes parmi les facteurs exprimés.
Ce document est protégé par la loi sur le droit d'auteur. L'utilisation des services d'Érudit (y compris la reproduction) est assujettie à sa politique d'utilisation que vous pouvez consulter en ligne.

https://apropos.erudit.org/fr/usagers/politique-dutilisation/ 


\title{
DUBBING AS AN EXPRESSION OF NATIONALISM
}

MARTINE DANAN

Southfield, Missouri, USA

\begin{abstract}
Résumé
On cherche à savoir pourquoi le public de certains pays préfère les films doublés alors qu'ailleurs les sous-titres sont plus populaires. Pour saisir l' importance accordée à chacune de ces formes de traduction dans un pays donné, il faut les étudier en tant que phénomènes linguistiques et en tant qu'éléments de l'expression cinématographique. Ce qui conduit à l'étude des différentes caractéristiques de la production cinématographique de divers pays. On démontre que le choix de la forme de traduction s'appuie sur divers facteurs d'identité culturelle et linguistique d'un pays; il est possible d'identifier des constantes parmi les facteurs exprimés.
\end{abstract}

The preference for film dubbing or subtitling has often given rise to passionate debate concerning the aesthetic value and the linguistic quality of the translated material. Arguments about qualitative criteria, however, do not explain why entire countries clearly favor dubbing and others prefer subtitling. The purpose of this paper is to study the reasons for these preferences in some representative Western European countries. To fully understand the significance of dubbing and subtitling, these two forms of film translation must be treated as linguistic phenomena and as elements of cinematographic expression. In order to approach dubbing and subtitling from these two angles, national characteristics of both film production and language policies and practice will be examined. It will be shown that the choice of either dubbing or subtitling is based on major factors extending to the cultural and linguistic identity of a nation, and that some clear patterns emerge from these factors.

\section{DUBBING IN LARGER COUNTRIES: BEYOND ECONOMIC MOTIVATIONS}

There appears to be a clear dichotomy in film translation practice between larger and smaller countries. Dubbing is generally used in France, Germany, Italy and Spain. England also favors dubbing, but the translation issue is not as significant there since the vast majority of imported movies are American and do not require any translation. Subtitling is always used in smaller countries such as Belgium, Switzerland, the Netherlands and the Scandinavian countries. The reason for this dichotomy has often been explained in terms of economic differences: dubbing, a far more expensive and time-consuming practice, is used in larger, wealthier countries that expect high box office receipts. Subtitling, on the other hand, is the economical solution reserved for the restricted markets of smaller countries.

The assumption, however, that the choice of dubbing or subtitling is essentially dependent on economic reasons cannot be accepted at face value. Even though it would be more cost-effective to release the same version across national boundaries wherever the same language is spoken, this type of distribution usually does not occur. For 
instance, dubbed versions of films released in France are not distributed in the Frenchspeaking parts of Belgium and Switzerland. Instead, most films are distributed with bilingual subtitles (such as Flemish-French films in Belgium). The lack of acceptance of standardized French versions is all the more surprising as French-speaking Swiss and Belgians are usually geographically concentrated and function culturally as monolingual groups.

Scholars who believe that the choice of dubbing is primarily based on greater economic gain also argue that most viewers would prefer dubbing if they were given a choice. They contend that a dubbed film has greater mass appeal because most people prefer not to read titles. Some studies based on television viewers, however, refute the notion that spectators object to reading subtitles. The studies show that in countries where subtitling is predominant, people prefer titles and do not perceive them as a problem (except for senior citizens, who are slower readers). On the other hand, in countries where dubbing is used, people clearly prefer this presentation. Luykken (1987: 61), for example, reports that according to a recent survey, $82 \%$ of Dutch viewers preferred subtitling, but only $36 \%$ of British viewers chose subtitling. In other words, people seem to prefer whatever method they were originally exposed to and have resultantly grown accustomed to.

The question remains how a preference for one translation method was established originally. Since dubbing is a more expensive and complex process, one might wonder what justified the additional cost and effort involved. Were some nations less willing than others to accept subtitling? Was there any governmental pressure put on distributors to encourage dubbing in some countries? Were there, beyond profit, some political or nationalistic considerations at stake? These questions can only be answered by examining the historical context of early film translation. Individual government policies in Western Europe with regard to film production and importation (especially from Hollywood) also need to be considered.

\section{EARLY FILM PRODUCTION AND AMERICAN DOMINATION}

During the silent film era, titles used between scenes could be easily translated and substituted for the original ones. A translation problem only arose with the birth of the talkies in the late twenties. For a few years, until 1932-33, American film companies tried to solve the translation problem by producing multiple-language versions of the same film. Huge studios were built for this purpose in Joinville, France. The same set and scenario were used for each national group of directors and actors, and sometimes as many as fifteen versions of a film were made. This system, which soon proved to be uneconomical, inefficient and artistically poor (productions were even boycotted by the public in France), was quickly abandoned. The Joinville studios were then turned into a dubbing facility (Robinson 1973: 174). From that point on, films had to be either dubbed or subtitled in order to be distributed worldwide.

All the smaller countries suffered from the introduction of sound into movies. The production of movies started to require much higher budgets than most of these countries could afford. These countries were also limited by a small home market, and they could no longer easily export movies to larger countries because of language barriers. Therefore, home production declined and importation dramatically increased. Larger countries were better equipped to continue producing their own films but were also faced with powerful American competition.

American companies' monopoly on the entire European film industry was at its strongest between the early thirties and the early fifties. When sound films started to 
become popular around 1930, American companies had a monopoly on the recording equipment and, for a few years, tried to prevent European countries from competing with them (Robinson: 170-171). World War II greatly affected film production and trade, but American exports to Europe resumed stronger than ever after the war. The MPEA (Motion Picture Export Association) was created in 1945 to reestablish American domination of world markets. European countries, whose economies had been greatly weakened by the war effort, were easily flooded with new films as well as with the 2500 backlogged American movies produced during the war. American domination over all European markets reached its peak between 1949 and 1952. By 1952, American industry had begun to decline, while larger European countries had adopted protective measures (Gruback 1969: 49-50).

\section{PROTECTIONISM IN LARGER WESTERN EUROPEAN COUNTRIES}

Larger European countries tried to protect themselves early against American domination in the film industry. They set up import quotas aimed at protecting local industry from foreign competition. As early as 1925 , Germany was the first country to set up barriers against American film imports. It was soon followed by France (Gruback: 16). Between 1930 and 1939, France established strict limits on the number of foreign movies that could be imported. Thanks to these measures, French films grossed $65 \%$ of domestic receipts in 1938 (Andrew: 172).

After World War II, France, Italy and Spain reestablished strict import quotas on films. As a result of these regulations, the number of American movies imported to Italy dropped from 668 in 1948 to 394 in 1950, and to 285 dubbed films in 1951 (Gruback: 26). In France, a 1948 trade agreement with the United States allowed 121 dubbed American movies into the country annually, out of a total of 186 dubbed movies. Similar agreements were ratified until the early sixties in France and Italy, at which point protectionism was no longer considered necessary (Gruback: 22-23). France and Italy also created taxes on imported films, stipulated that profits by American companies had to be reinvested locally, and set up screen quotas. By 1948 in France, for instance, at least 5 out of 13 weeks in theater programming had to be set aside for French movies. Spain, too, regulated the number of American movies allowed into the country. By 1958, Spain even imposed a point system that established a ratio between the number of films American distributors could export to Spain and the number of Spanish movies they would distribute in exchange. Spain's protectionism lasted longer than in the other larger European countries - until the late sixties - because of its political situation and a relatively weaker domestic film industry. 


\section{Domestic and Foreign Film Production in Selected European Countries between 1951 and 1962 (see endnote)}

\begin{tabular}{|c|c|c|c|c|c|c|c|c|c|}
\hline & Ital. & W.Ger. & Spain & Swed. & Denm. & Finl. & Norw. & Neth. & Total \\
\hline $\begin{array}{l}\text { Domestic } \\
\text { Films }\end{array}$ & 1915 & 1164 & 877 & 309 & 182 & 254 & 138 & $\mathrm{~N} / \mathrm{A}$ & \\
\hline Imports & & & & & & & & & \\
\hline American & 2613 & 2441 & 1162 & 2061 & 2209 & 2352 & 2251 & 2438 & 17527 \\
\hline British & 482 & 461 & 307 & 581 & 458 & 442 & 625 & 670 & 4026 \\
\hline Italian & $\mathrm{N} / \mathrm{A}$ & 372 & 340 & 198 & 133 & 256 & 203 & 393 & 1895 \\
\hline French & 478 & 514 & 292 & 437 & 372 & 472 & 395 & 659 & 3619 \\
\hline W.German & 293 & N/A & 153 & 230 & 428 & 367 & 346 & 749 & 2566 \\
\hline Swedish & $\mathrm{N} / \mathrm{A}$ & $\mathrm{N} / \mathrm{A}$ & $\mathrm{N} / \mathrm{A}$ & N/A & 155 & 134 & 294 & N/A & 33 \\
\hline $\begin{array}{l}\text { Total } \\
\text { Imports }\end{array}$ & 4406 & 4768 & 2816 & 3765 & 3898 & 4419 & 4478 & 5232 & \\
\hline $\begin{array}{l}\text { Domestic } \\
\text { Films } \\
\% \text { of Total } \\
\text { Films }\end{array}$ & 30.3 & 19.6 & 23.7 & 7.6 & 4.5 & 5.4 & 3 & N/A & \\
\hline $\begin{array}{l}\text { Imported } \\
\text { Films } \\
\text { \% of Total } \\
\text { Films }\end{array}$ & 69.7 & 80.4 & 76.3 & 92.4 & 95.5 & 94.6 & 97 & & \\
\hline
\end{tabular}

\section{GOVERNMENT SUPPORT OF FILM PRODUCTION IN LARGER WESTERN EUROPEAN COUNTRIES}

While American imports were restricted, France, Italy, Spain and Germany strongly encouraged their national film industry production through active government support, loans and subsidies. Figures compiled for film imports and domestic production between 1951 and 1962 (see chart above) reveal that, even though American movies dominated the Italian, German and Spanish markets, domestic production represented a significant share of the total production. Even though the Spanish national production was smaller than in the other large countries, stricter import regulations ensured that Spanish films amounted to over $23 \%$ of the number of movies released in Spain during these years.

Other statistics show that, as a result of government support in Italy, about 800 films were produced between 1945 and 1953, and over 200 a year between 1958 and 1968. In France production increased from 72 films in 1945 to 126 in 1953 (Robinson: 258). There, the number of French films in circulation was nearly as high or, since 1959, even greater than the number of American movies (Gruback: 65). France was also the only country where gross box office receipts for French films from 1952 to 1966 consistently represented about half the gross receipts, and this figure was always significantly higher than receipts for American movies (Gruback: 55).

Compared to the situation in larger countries, the number of films produced in the smaller European countries indicated on the chart above lagged far behind. In spite of their smaller markets, each of these countries imported almost as many American movies 
as Italy or West Germany. They also imported a significant number of French, Italian and German films.

\section{NATIONALISTIC THEMES IN POST-WAR SPANISH, GERMAN, ITALIAN AND FRENCH FILMS}

In addition to protecting themselves from American domination and promoting domestic production, France, Italy, Germany and Spain also encouraged a national cinema projecting an image of strong national identity.

\section{FILMS UNDER FRANCO}

Because of Franco's relentless control of power, most Spanish films until the sixties shared some simplistic nationalistic themes. One major theme was the official version of the Civil War which became a holy war against the evil Republicans. Another common genre was the war epic evoking Spain's glorious past. Folkloric flamenco films also combined popular entertainment, escape from reality and an emphasis on a distinctly national culture (Higginbotham: 500). The government supplied subsidies and helped promote the distribution of these types of movies.

\section{FILMS IN POST-WAR GERMANY}

The 1945-1962 era in the German film industry should be seen as a transition period in which artists were trying to deal with the country's past and with the question of national identity (Rentschler: 209). One major theme in postwar German film was that people were victims in the hands of Fate, namely history. A major genre in the fifties was the "homeland film": over 300 "homeland" movies (1/5 of the entire German production) were made between 1947 and 1960. These homeland films provided "comforting images of green fields untouched by devastation", an escape from the daily grim reconstruction (Rentschler: 215). Filmmakers also reverted to past models, either by adapting literary works that depicted the lost culture from before World War I, or by working on remakes of popular comedies and musicals from the Weimar Republic. At the same time, some filmmakers were trying to look towards the future and present an optimistic view of reconstruction. During the "Adenauer era" (1949 to 1963), which was characterized by its fierce anti-communism and unconditional support of the American model, state loans and prizes encouraged film production supportive of the regime.

\section{FILMS IN POST-WAR ITALY}

Post-war Italian cinema became known worldwide for the neorealist style it pioneered. Neorealist films emphasized social themes such as the war and poverty. They used natural settings and non-professional actors, unlike Hollywood's studio and star system. Many commercial films incorporated neorealist themes into farcical elements or melodramatic action that appealed to the masses. One successful genre was comedy with social criticism overtones, which came to be known as commedia all'italiana (Bondanella: 356). Thus, Italian filmmakers adapted some of Hollywood's commercial codes while managing to create a seemingly authentic national expression.

\section{POST-WAR FRENCH FILMS}

Post-war French films implicity shared common nationalistic themes. France always felt it had a cultural mission within the film art form. The word "quality", first used to define French film in 1935, had become by 1945 an actual rhetorical term often contrasted to Hollywood's "quantity" (Andrew: 171). Filmmakers attempted to portray a refined, superior culture based on literary adaptations of French classics, the use of elaborate designs and fashion, and moral themes. Thus, movies helped advertise for 
French artistic traditions, good taste, and indirectly for products like perfume and haute couture (which could be exported) (Andrew: 172-173).

In the larger European countries, cinematographic production represented more than a large domestic industry. Cinema was considered to be a vital part of the national culture. By evoking a glorious past, by portraying national themes that spectators could relate to, films became an essential part of the nationalistic rhetoric promoted by the state.

\section{FASCIST GOVERNMENTS' CONTROL OF THE FILM INDUSTRY}

\section{FILM AS AN IDEOLOGICAL TOOL}

In Germany, Italy and Spain, the very foundations of the post-war film industries were a direct legacy of earlier fascist governments. Nazi Germany and Fascist Italy, in the thirties and forties, and Spain under Franco's early leadership, set about to tightly control their national film productions. The three fascist countries realized the appeal and impact films with sound could have on the masses. In an effort to build strong nationalistic states and spread fascist ideology, these countries nationalized and reorganized their respective film industries and created infrastructures that are still central to their film industries today.

From the very beginning of the Third Reich, the German film industry was placed under government control. All aspects of film production and distribution depended on the government-owned UFI which controlled its subsidiary, the UFA (Universum Film A.G.). The UFA was supervised by the Ministry of Propaganda led by Joseph Goebbels. Movies had a dual function: propaganda and escapism, both within Germany and in the occupied territories. The market for German films increased from 250 million viewers in 1933 to one billion in 1942 (Robinson: 220). After the war the UFI monopoly remained intact, even though it passed into private hands in 1956.

Like Hitler, Mussolini reorganized the Italian film industry. In 1935, he established the Centro Sperimentale, Rome's large film school where many of Italy's famous postwar directors were trained. The huge Cinecittà Studios, which still play a major role in modern Italian production, were founded by Mussolini in 1937 (Bondanella: 347).

Franco also endeavored to strictly control the Spanish movie industry, particularly through rigid film censorship until the fifties (when, in an effort to achieve economic prosperity, Franco started liberalizing his regime).

\section{REGULATIONS IN FAVOR OF DUBBING}

With regard to the foreign movies that were allowed to be imported into these countries, governments also established guidelines about the versions that could be distributed. Dubbing was often imposed by law. Mussolini prohibited any non-dubbed version from entering his country. Initially, Franco also ruled against any non-dubbed version; then, he clearly favored dubbed versions. According to a 1955 agreement, American distributors could bring only 80 films a year to Spain. Out of these 80 films, 68 had to be dubbed and the 12 others subtitled (Gruback: 27). In Hitler's Germany dubbing was systematically promoted as the result of the UFA providing dubbing parts to unemployed actors (Vöge 1977: 120). Originally, at least, dubbing was often the result of an overt governmental policy in a nationalistic environment.

\section{NATIONALISTIC LANGUAGE POLICIES: IN THE DEFENSE OF NATIONAL UNITY AND GLORY}

The clear preference for dubbing in a nationalistic context cannot be fully understood without examining general language policies in the countries involved. The three fascist 
governments of Spain, Italy and Germany had similar language policies. They all insisted on having one standardized national language for the sake of national unity, and forbade minority groups to speak their own dialects or languages. These policies represented an unprecedented effort to strengthen a linguistic and political unity that was still fragile. In Spain, until Franco came to power, Castilian had failed to eradicate powerful minority languages - Galician, Basque and Catalan. In Germany, Hitler's ruthless pangermanic policy was an effort to recapture Germany's past grandeur and unity, briefly achieved between 1890 and 1914. In Italy, Mussolini came to power at a time when regional dialects were still extremely strong and seemed to undermine the notion of national unity.

Standardized French, in contrast, was historically a successful instrument of political and cultural centralization. For centuries, proper French has been constantly defined and defended by grammarians and members of the French Academy. Within France and in its African colonies, no other language was allowed to compete with French, a supposedly superior universal language. Even today, efforts are being made to protect the purity of the French language and to maintain the influence of French in the world.

Whether linguistic and political unity existed prior to the twentieth century or not, standard French, Spanish, Italian and German have played a similar nationalistic role in the twentieth century. To function in a nationalistic manner, language combines six main characteristics according to Fasold (1983: 77):

- "Symbol of national identity for a significant proportion of the population

- Widely used for some everyday purposes

- Widely and fluently spoken within the country

- No major alternative nationalist languages in the country

- Acceptable as a symbol of authenticity

- Link with the glorious past."

This sense of a "glorious past" can be created for ideological reasons and often reflects an idealized history. A complete nationalistic rhetoric, to which cinematographic expression belongs, helps create this sense of national pride.

\section{NATIONALISTIC FUNCTION OF TRANSLATION}

A strong nationalistic system tends to be closed and reject or limit outside influences, since the home system is perceived as the embodiment of a firmly-established, superior tradition. Translation, in the case of a strong system, is relegated to a "secondary position" and is "modelled according to norms already established by a dominant type" (Toury 1986: vol. 2, 1122). Translation in a nationalistic environment must therefore be target-oriented in order to make foreign material conform as much as possible to the local standards. In this sense, dubbing is target-oriented.

Dubbing is an attempt to hide the foreign nature of a film by creating the illusion that actors are speaking the viewer's language. Dubbed movies become, in a way, local productions. Interestingly enough, in the statistics published annually by the Italian film association, dubbed foreign movies are counted in the number of "Italian version" movies. Foreign utterances are forced to conform to the domestic norms and frame of reference. Even a foreign dialect will have to be matched to some vague equivalent known in the target system (for example, Black American English dubbed into Bavarian German). Dubbing, in short, is an assertion of the supremacy of the national language and its unchallenged political, economic and cultural power within the nation's boundaries.

Subtitling, on the other hand, is an extreme form of source-oriented translation. "Subtitles rather correspond to an extreme strategy, in which the original is not deleted, 
but in which it is just supported, - second hand, in a subsidiary way - by a written summary. The use of subtitling corresponds to the so-called adequate translation (the Source System oriented translation), as a bilingual book does; it is partly a kind of nontranslation" (Lambert: 131). Viewers (who can even stop reading subtitles if they make a conscious effort to do so) are constantly reminded of the foreignness of a film by the presence of the original soundtrack. Subtitling indirectly promotes the use of a foreign language as an everyday function in addition to creating an interest in a foreign culture. No extreme nationalistic society could allow a foreign language to reach the masses so easily and compete with its national language.

\section{CONCLUSION}

Subtitling and dubbing represent two extremes on the translation spectrum because they originate from two opposite types of cultural systems. Subtitling corresponds to a weaker system open to foreign influences. Dubbing results from a dominant nationalistic system in which a nationalistic film rhetoric and language policy are promoted equally. Suppressing or accepting the foreign nature of imported films is a key to understanding how a country perceives itself in relation to others, and how it views the importance of its own culture and language.

Further studies should determine whether this nationalistic pattern for dubbing also applies to other international film markets. Is dubbing the norm in India, for example? Although India is a major multilingual film producer, Hindi is the dominant film production language. In addition, India exports to large illiterate audiences in the Third World. What is the situation in the Soviet Union, which is also multilingual but with a strongly centralized nationalistic structure? How did Peron's Argentina, with its large Italian immigrant population, compare to European fascist countries with respect to film production and dubbing?

Another set of questions that should be addressed in further studies concerns television. Comparing national television policies in the fifties and sixties to film language policies could reveal interesting parallels, since most television networks were placed under direct government control. One might also wonder how the changing structure of European communication, with increasing international cable and satellite programming, will affect national networks. At the same time as European unity is increasing, small minorities are becoming more vocal and claiming their rights to a regional culture. One may question how long patterns based on European nationalism will last and what new patterns might be emerging. If new patterns do emerge, will dubbing become a practice of the past?

\section{ENDNOTE}

These figures were based on three types of statistics provided by various official agencies or governments. In some countries, the actual numbers of imported films were provided; in others, the numbers of released films were reported; in some other cases the numbers were based on films submitted for censorship. In spite of minor inconsistencies, combining the three kinds of figures provides a significant way of comparing film imports. Another problem is linked to the nationality label given to the movies, in particular with coproductions and films having large shares of foreign investments. West Germany, for example, has a separate entry for FrenchItalian coproductions (totaling 285 movies for the 1951-1962 period)

These figures are based on the following data (quoted in Gruback: 39-51):

- "Nationality of Feature Films imported" - Source: Associazione Industrie cinematografica ed Affini (Italy)

- "Nationality of Feature Films Authorized for Exhibition" - Source: Ministerio de Información y Turismo (Spain)

- "Nationality of Films Released" - Source: Spitzenorganisation der Filmwirtschaft (Germany) 
- "Nationality of Feature Films Released" - Source: Sveriges Biografagareforbund and Sveriges Filmuthyrareforening (Sweden)

n "Nationality of Feature Films Submitted for Censorship" - Source: Staten Filmcensur (Denmark)

- "Nationality of Feature Films Released" - Source: Suomen Filvuokraajaliitto and Suomen Elokuvatoimistojen Liitto (Finland)

- "Nationality of Feature Films Released" - Source: Kommunale Kinematografers Landsforbund (Norway)

- "Nationality of Feature Films Imported" - Source: Nederlandsche Bioscoop-Bond (The Netherlands)

\section{ACKNOWLEDGMENT}

I am particularly grateful to José Lambert, Director of the Penn-Leuven Institute for Literary and Cultural Studies. He gave me the opportunity to attend the 1988 Summer Institute and participate in his translation workshop, which inspired this paper.

I would also like to thank Dirk Delabastita, from the University of Leuven, and Johan Nootens, from BRT (Belgian Radio and Television - Dutch network) for their bibliographic assistance.

Finally, I would like to thank Johan Nootens, Rachel Russo from RTBF (Frenchspeaking Belgian Radio and Television network), Marcel Braeckelere from Laboratories Titra, and Marc Van Calck from Établissements Dassonville for discussing their subtitling techniques and giving me a tour of their studio facilities.

\section{BIBLIOGRAPHY}

ANDREW, Dudley: "France", Luhr.

BONDANELLA, Peter: "Italy", Luhr.

FASOLD, R. (1983): The Sociolinguistics of Society, London, Blackwell.

GRUBACK, Thomas H. (1969): The International Film Industry: Western Europe and America since 1945, London, Indiana Univ. Press.

HIGGINBOTHAM, Virginia: "Spain", Luhr.

LAMBERT, José (1988): "West-European Traditions in Translational Policy: A Report on Research in Progress", Translation, Our Future. La traduction, notre avenir, XIth World Congress of FIT. XI Congrès mondial de la FIT, Ed. Paul Nekeman. Maastricht, Euroterm, pp. 128-133.

LUHR, William (Ed.) (1987): World Cinema since 1945, New York, Ungar.

LUYKKEN, Georg (1987): "In Other Words - Part II", Cable \& Satellite Europe, June 1987, pp. 57-61.

RENTSCHLER, Eric: "Germany", Luhr.

ROBINSON, David (1973): The History of World Cinema, New York, Stein and Day.

TOURY, Gideon (1986): “Translation", Encyclopedic Dictionary of Semiotics, Ed. Thomas A. Seboek, 2 vols., Berlin, DeGruyter.

VÖGE, Hans (1977): "The Translation of Films: Sub-Titling Versus Dubbing", Babel, 23-3, pp. 120-125. 